\title{
Working capital management and SMEs profitability: Portuguese evidence
}

\author{
Maria Amélia Pais \\ Coimbra Sul Group of Schools, Coimbra, Portugal, and \\ Paulo Miguel Gama \\ Faculty of Economics, University of Coimbra, Coimbra, Portugal
}

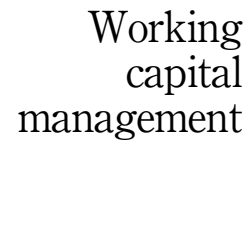

341

Received 12 November 2014 Revised 2 January 2015 Accepted 26 January 2015

\begin{abstract}
Purpose - The purpose of this paper is to provide empirical evidence on the effects of working capital management on the profitability of small and medium-sized Portuguese firms.

Design/methodology/approach - Panel regressions (fixed effects) and instrumental variables were used to model a sample of 6,063 Portuguese small and medium-sized firms (SMEs), covering the time period 2002-2009. Also, industry-demeaned values and industry-specific dummy variables allow for industry-specific effects robustness tests.

Findings - Results indicate that a reduction in the inventories held and in the number of days that firms take to settle their commercial liabilities and to collect payments from its customers are associated to higher corporate profitability. Similar results are obtained when industry-specific effects are controlled, supporting the robustness of the previous analysis. The relevance of quadratic dependences of the profitability on some variables was also identified and suggests a decreasing trend of return on assets with increasing values of the working capital management characteristic variables. Practical implications - The practice of more aggressive working capital management policies increase firms' profitability. Moreover, the importance of a good practice in working capital management is stressed by the evidence suggesting the existence of an optimal level for the working capital components. Originality/value - The consensus that SMEs play a crucial role in the development of the national economy, the lack of published industry wide studies of this type for the case of Portugal, justifies the importance of the present study.
\end{abstract}

Keywords Profitability, Small to medium-sized enterprises, Working capital management

Paper type Research paper

\section{Introduction}

It is generally accepted the important role played by small and medium-sized firms (SMEs) in the development of the world economy, as sources of innovation and employment, and their dynamic relationship of interdependence with larger firms (Audretsch, 2002; Ellis and Tailor, 2011).

As generally in European economy, the segment of SMEs in the Portuguese market is the main generator of employment and productivity, assuming a pillar of corporate structures. In fact, these companies are perfectly dominant in the national business structure. According to the Portuguese National Institute of Statistics, SMEs represented over 99 percent of the business units operating in the country and were responsible for 77 percent of the jobs and for more than one-half of the total turnover, in 2011. Considering the specificities of this business segment, the expansion and sophistication of financial markets and the high cost of credit for this segment, the analysis of their financial decisions is of particular relevance.

The corporate finance literature presents traditionally results on long-term financial decisions, including capital structure, investments, dividends and company valuations

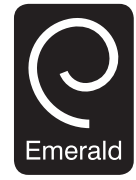

International Journal of Managerial Finance pp. $341-358$ 1743-9132 DOI 10.1108/IJMF-11-2014-0170 
IJMF

11,3

342

(García-Teruel and Martínez-Solano, 2007). However, most firms have a large amount of cash invested in working capital, as well as substantial amounts of short-term payables, as a source of financing (Deloof, 2003). Since these have a direct impact on liquidity and profitability (Appuhami, 2008), inattention to the liquidity management process may cause severe difficulties and losses due to adverse short-run developments even for a firm with favorable long-run prospects (Richards and Laughlin, 1980).

Many factors, both internal and external, can influence the decisions of corporate managers about the level considered optimal for current assets and liabilities. In general, the working capital management policy is driven by one of two approaches: the first consists of practicing an aggressive policy, with high levels of non-current assets and little investment in current assets, particularly with low cash balances, low level of inventories and a very limited grant credit to customers, so as to generate more profits. However, it presents a high risk with regard to the possibility of insufficient funds for daily operations and to pay short-term debts (Van-Horne and Wachowicz, 2008). The second is based on a more flexible and conservative policy, with less investment in non-current assets and more in current assets, especially with larger cash balances, inventory levels and customer loans, which can create value for the company (Nazir and Afza, 2009).

Most of SMEs do not have long-term assets such as buildings or vehicles and, consequently, the percentage of current assets over total assets is quite high (García-Teruel and Martínez-Solano, 2007), i.e., most of the assets consist of inventory, accounts receivable and cash balances. In this sense, an efficient working capital management is crucial because it directly affects the company's growth and long-term survival, since high levels of working capital are needed to meet the production and sales growth.

Also, SMEs often have a lack of market power and resources to manage their trade debtors effectively, which increase the risks of late payment and defaulting debtors (Atrill, 2009).

Many studies have been published with the aim of establishing relations between working capital management and profitability. Most of them have found a negative relationship between profitability and cash conversion cycle - which represents the length of time between the acquisition of raw materials and other inputs and the inflow of cash from the sale of goods, and reflects the decisions on the amount invested in inventory, loans to customers and credit obtained from suppliers - pointing to the idea that the practice of an aggressive policy of working capital management tends to improve corporate profitability (see Jose et al., 1996; Deloof, 2003; Lazaridis and Tryfonidis, 2006; Raheman and Nasr, 2007; García-Teruel and Martínez-Solano, 2007; Falope and Ajilore, 2009; Karadagli, 2012, among others).

More recent studies, Silva (2011) and Gomes (2013) found the existence of a non-monotonic (concave) relationship between working capital level and firm profitability, which indicates that firms have an optimal working capital level that maximizes their profitability (see also Baños-Caballero et al., 2012 for evidence concerning Spanish SMEs).

In what pertains to the components of the cash conversion cycle, studies (Deloof, 2003; Falope and Ajilore, 2009) reported the existence of a negative relationship between profitability and the number of days accounts receivable, number of days of inventory and number of days accounts payable. Accordingly, they raise the possibility, granted to managers, to create value for shareholders, having the cash conversion cycle reduced to a minimum. This relationship is partly confirmed in a study to seven-listed companies of the oil and gas sector of Pakistan for the period 2001-2005 (Shah and Sana, 2006). 
A further analysis (García-Teruel and Martínez-Solano, 2007) differs, however, in to the number of days accounts payable: the relationship loses significance when controlling for the possibility of endogeneity.

In order to provide empirical evidence on the effects of working capital management on profitability of Portuguese SMEs, a study using the methodology of panel data, over a sample of 6,063 SMEs in the time period 2002-2009 was conducted.

Results indicate that a reduction on the inventories held and in the number of days that firms take to settle their commercial liabilities and to collect payments from its customers, are associated to higher corporate profitability, and a similar outcome occurs by reducing their cash conversion cycle. However, when controlled for possible effects of endogeneity, the variable number of days accounts receivable shows a positive relationship, which suggests the possibility of a conflict of influences between corporate profitability and the credit that firms provide to customers.

The consensus that SMEs hold relevance in the development of its national economy and the lack of studies of this type for the case of Portuguese SMEs, support the relevance of the present study.

This research paper is organized as follows: the present section describes the motivation of the study and presents the theoretical foundations, Section 2 describes the research design and Section 3 presents the empirical results. Finally, the overall findings and conclusions are summarized in Section 4.

\section{Research design}

In what follows data and variables used are presented and, estimation procedures described. Finally, a statistical characterization of the sample is presented.

\subsection{Data}

This study utilizes a data panel of non-financial Portuguese SMEs. The data were obtained from the SABI database (Iberian Balance Sheets Analysis System) for an eight years period (2002-2009). This database was developed by the Bureau Van Dijk and contains accounting and financial information for more than 350,000 Portuguese firms.

The selection of SMEs was carried out according to the requirements established by the European Commission's recommendation 2003/361/CE, May 6, on the definition of SMEs. Companies that meet the following requirements for at least five of the eight years under consideration were selected: fewer than 250 employees and turnover below $€ 50$ million or total annual balance sheet below $€ 43$ million.

In addition to these selection criteria, several filters were applied, eliminating companies with incomplete data in the time period under examination or no operating activity. Given their specific accounting procedure, companies in the financial sector were not considered. Finally, companies that had, for several variables, 1 percent of the extreme values were eliminated. As a result of the application of these filters, the final sample consisted of 6,063 companies.

\subsection{Variables}

For this analysis, the return on assets (ROA) was used as the dependent variable. The independent variables are divided into two groups. The first considers the variables related to the management of working capital and a second that includes control variables. 
IJMF 11,3

The independent variables considered related to the management of working capital include the number of days accounts receivable (AR), calculated as $\left(365 \times\right.$ [accounts receivable/(sales $\left.\left.\times\left(1+t_{\mathrm{VATS}}\right)\right)\right]$ ) where $t_{\mathrm{VATs}}$ is the average rate of VAT, the number of days accounts payable (AP), calculated as $(365 \times$ [accounts payable/purchases and external supply $\left.\times\left(1+t_{\mathrm{VAT}}\right)\right]$, where $t_{\mathrm{VATp}}$ is the average rate of VAT, the number of days of inventory (INV), calculated as $(365 \times$ [inventories/cost of sales]) and the cash conversion cycle (CCC), calculated as $A R+I N V-A P$.

The control variables considered in this study were the size of the firm (SIZE), measured as the logarithm of assets, the growth in its sales (SGROW), calculated as sales $_{1}-$ sales $_{0} /$ sales $_{0}$, its leverage (DEBT), given as total debt/total assets, current assets ratio (CAR), obtained through current assets/total assets and current liabilities ratio (CLR), measured as current liabilities/total liabilities (we thank an anonymous referee for suggesting the latter variables).

Following García-Teruel and Martínez-Solano (2007), and since the economic environment can be reflected in the profitability of the companies, a control variable was included to account for the effect of the economic cycle in investment in working capital. This is a measure of the annual GDP growth, denoted GDPGR. These data were collected from the information available on the Eurostat annual GDP growth for Portugal.

\subsection{Estimation}

Estimates of the effects of working capital management on profitability of SMEs were obtained for:

$$
\begin{aligned}
& R O A_{i t}=\beta_{0}+\beta_{1} I N V_{i t}+\beta_{2} S I Z E_{i t}+\beta_{3} S G R O W_{i t}+\beta_{4} D E B T_{i t} \\
& +\beta_{5} G D P G R_{i t}+\beta_{6} C A R_{i t}++\beta_{7} C L R_{i t}+v_{i}+\varepsilon_{i t} \\
& R O A_{i t}=\beta_{0}+\beta_{1} A P_{i t}+\beta_{2} S I Z E_{i t}+\beta_{3} S G R O W_{i t}+\beta_{4} D E B T_{i t} \\
& +\beta_{5} G D P G R_{i t}+\beta_{6} C A R_{i t}++\beta_{7} C L R_{i t}+v_{i}+\varepsilon_{i t} \\
& R O A_{i t}=\beta_{0}+\beta_{1} A R_{i t}+\beta_{2} S_{Z Z E_{i t}}+\beta_{3} S G R O W_{i t}+\beta_{4} D E B T_{i t} \\
& +\beta_{5} G D P G R_{i t}+\beta_{6} C A R_{i t}++\beta_{7} C L R_{i t}+v_{i}+\varepsilon_{i t} \\
& R O A_{i t}=\beta_{0}+\beta_{1} C C C_{i t}+\beta_{2} S I Z E_{i t}+\beta_{3} S G R O W_{i t}+\beta_{4} D E B T_{i t} \\
& +\beta_{5} G D P G R_{i t}+\beta_{6} C A R_{i t}++\beta_{7} C L R_{i t}+v_{i}+\varepsilon_{i t}
\end{aligned}
$$

where in summary, $R O A$ measures the return on assets, $I N V$ the number of days inventories, $A P$ the number of days accounts payable, $A R$ the number of days accounts receivable, $C C C$ the cash conversion cycle, SIZE the company size, SGROW the sales growth, $D E B T$ the debt level, GDPGR the annual GDP growth, CAR the current assets ratio and CLR the current liabilities ratio. The two error components are $v_{i}$ and $\varepsilon_{i t}$. The first one measures the individual error component (a particular characteristic of each firm) and the other one considers the idiosyncratic error (unobservable factors that vary over time and affect $R O A_{i t}$ ).

This work resorted to different methods to analyze panel data: ordinary least squares (OLS), fixed and random effects. An $F$-test was conducted to compare the 
regular OLS and fixed-effects approaches, while a Hausman test, on the correlation between unique errors and regressors, was used to decide between random and fixed effects.

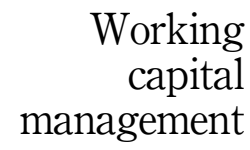

\subsection{Sample description}

Table I contains a descriptive statistics of the variables used for the sample constituted, in general, of small businesses with about $€ 2$ million in assets and a return of 5 percent. The number of days accounts payable and the number of days accounts receivable are about 68 and 73, respectively. The average sales growth is about 8 percent and the debt presents an average of 59 percent. Their current assets are on average 67 percent of total assets and 73 percent of total liabilities are current liabilities. During the period under review and because the annual rate of GDP growth in the years 2003 and 2009 was negative, the overall average for the period 2002-2009 was below 0.20 percent.

Since current assets and liabilities are related with the sector of activity (e.g. Jose et al., 1996; García-Teruel and Martínez-Solano, 2007), a sector-wise description for variables is also presented.

Through the analysis of Table II, it is apparent that the majority of the sectors display a low profitability. The sector $\mathrm{P}$ (education) with the lowest rate of debt and current liabilities ratio is among the most profitable groups, which comprises sectors $\mathrm{Q}$ (human health and social work activities), D (electricity, gas, steam and air conditioning supply) and I (accommodation and food service activities) that all together represent less than 2 percent of the sample. This last sector and also sector A (agriculture, forestry and fishing) display the second highest growth rate (44 percent).

Given its characteristics, sector I (accommodation and food service activities) registers the lowest value for the number of days accounts receivable. In opposition, sector B (mining and quarrying) presents the highest value for this variable, with about three months, placing it among the three that take longer to fulfill their commitments.

\begin{tabular}{lccccc}
\hline Variable & 1st quartile & Median & Mean & 3rd quartile & Maximum \\
\hline ROA & 0.02 & 0.04 & 0.05 & 0.07 & 0.38 \\
INV & 38.93 & 89.28 & 172.30 & 187.60 & $4,759.00$ \\
AP & 30.61 & 61.83 & 68.27 & 96.92 & 317.60 \\
AR & 28.08 & 70.01 & 73.23 & 106.60 & 330.40 \\
CCC & 43.69 & 102.70 & 177.30 & 201.30 & $4,666.00$ \\
SIZE & 6.82 & 7.52 & 7.63 & 8.34 & 10.67 \\
SGROW & -0.08 & 0.02 & 0.08 & 0.13 & 309.50 \\
DEBT & 0.46 & 0.62 & 0.59 & 0.74 & 1.00 \\
GDPGR & -0.013 & 0.004 & 0.002 & 0.014 & 0.018 \\
CAR & 0.51 & 0.70 & 0.64 & 0.85 & 1.00 \\
CLR & 0.58 & 0.79 & 0.73 & 0.93 & 1.00 \\
Number of firms & & & & & 6,063 \\
Number of observations & & & & 42,441
\end{tabular}

Notes: ROA, return on assets; INV, number of days of inventory; AP, number of days accounts payable; AR, number of days accounts receivable; CCC, cash conversion cycle; SIZE, firm size; SGROW, sales growth; DEBT, financial debt level; GDPGR, annual GDP growth; CAR, current assets ratio; CLR, current liabilities ratio. The INV, AP, AR and CCC variables are expressed in number of days; the ROA, SIZE, SGROW, DEBT, GDPGR, CAR and CLR variables are dimensionless

Table I. Descriptive statistics 
IJMF
11,3

346

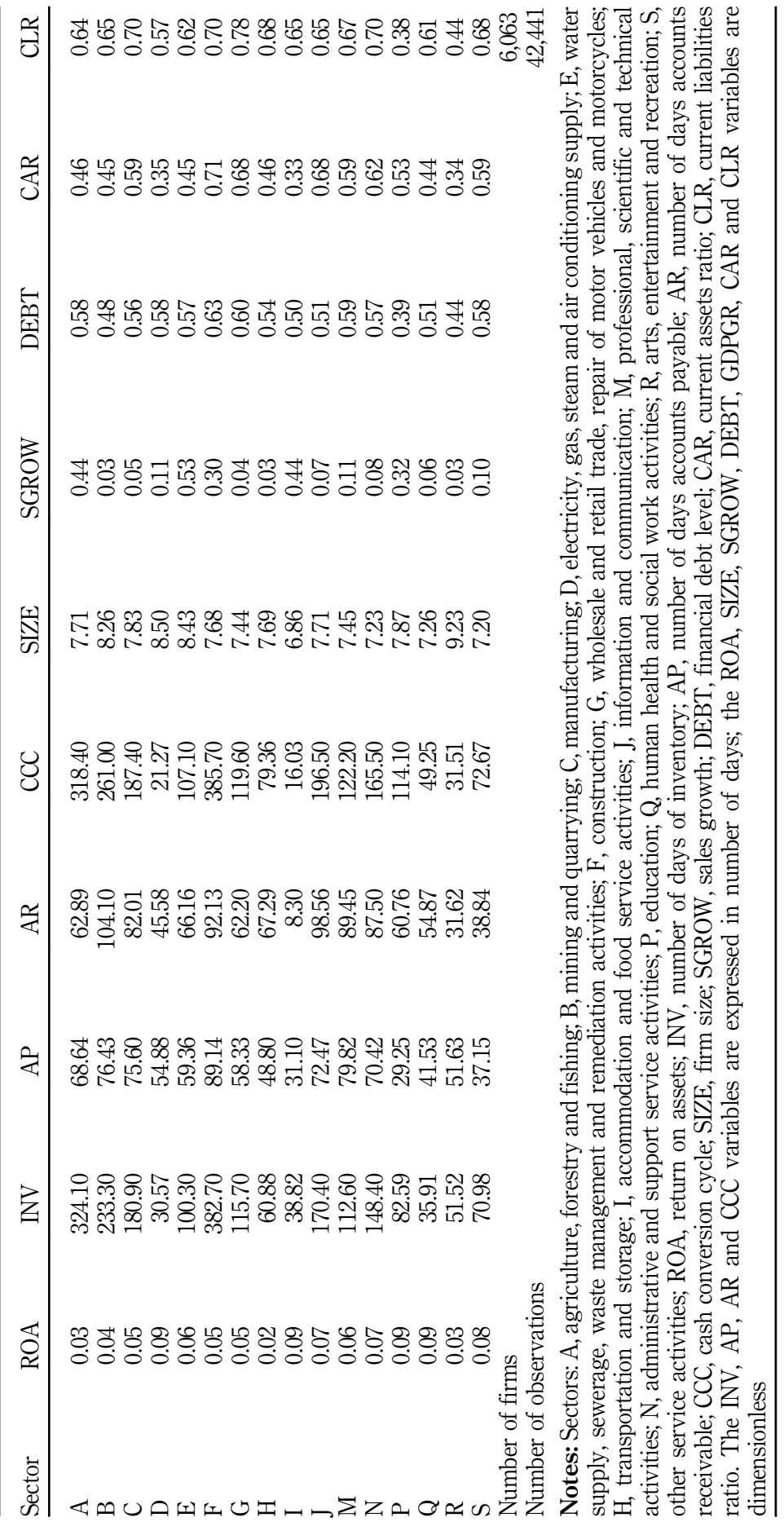

Table II.

Mean values, by sector 
Sector I (accommodation and food service activities) is the one holding the lowest value for the cash conversion cycle. This segment represented in the sample of 35 companies, associates a low value for the number of days of inventory to a number of days accounts receivable which is about one-fourth of the number of days accounts payable. Sector F (construction) possesses both cash conversion cycle and current assets ratio with the highest value. This sector, again given its characteristics, exhibits a high number of days of inventory, not compensated by the number of days accounts payable, which is around the number of days accounts receivable.

Concerning the sectors with the largest representation in the sample, $\mathrm{G}$ (wholesale and retail trade, repair of motor vehicles and motorcycles), 45 percent and $\mathrm{C}$ (manufacturing), 37 percent, it seen that both have the same value for profitability, but the first sector is generally found for values below the average of the global sample, for the number of days of inventory, number of days accounts receivable, days accounts payable and conversion cycle while for the latter the trend is toward higher values.

Table III presents the coefficients for the Pearson correlation matrix for the variables. A significant negative correlation between profitability with the number of days of inventory, number of days accounts payable and number of days accounts receivable is evident. Aligned with several studies (e.g. Deloof, 2003; Falope and Ajilore, 2009), this correlation suggests that a reduction of these deadlines could provide an increase in corporate profitability. Note that the negative correlation with profitability is also present when considering the combination of these three variables in the cash conversion cycle.

The same significant negative correlation of the profitability with the number of days of inventory, number of days accounts payable, number of days accounts receivable and cash conversion cycle is observed in the Pearson correlation matrix for the variables of the two most representative sectors of the sample.

\section{Results}

First we present univariate and multivariate results for the basic relation between working capital management characteristic and profitability. Next, we look into detail to robustness and endogeneity issues. Third, we look at industry effects using two alternative empirical approaches. Finally, we investigate possible non-linear effects.

\subsection{Working capital management and profitability}

With the aim of establishing whether there are significant differences among the most profitable companies and those in lower profitability, an univariate analysis was performed (see Table IV). The quartiles of ROA were calculated annually, and for each quartile were considered a lower limit, the lowest value of all years, and an upper limit, the largest value of all years. This afforded some overlap between ranges of ROA in quartiles. Sample firms were then grouped according to their value of ROA, and a study conducted for each quartile. The $t$-student test was applied to determine if the mean values of the fourth quartile are significantly different from that of the first.

Through inspection of the data illustrated in Table IV, it can be seen that firms with higher profitability (fourth quartile) have the lowest average values for the variables AR, $\mathrm{INV}, \mathrm{AP}$ and $\mathrm{CCC}$. These data are consistent with those in correlation matrix. However, it is not in first quartile that the AP and AR variables recorded the highest value.

With regard to the control variables DEBT and SIZE, for which the correlation matrix points toward negative relationships with the ROA, this analysis confirms that in the highest profitability group are located the lowest values for these two indicators. 
IJMF
11,3

348

Table III.

Correlation matrix

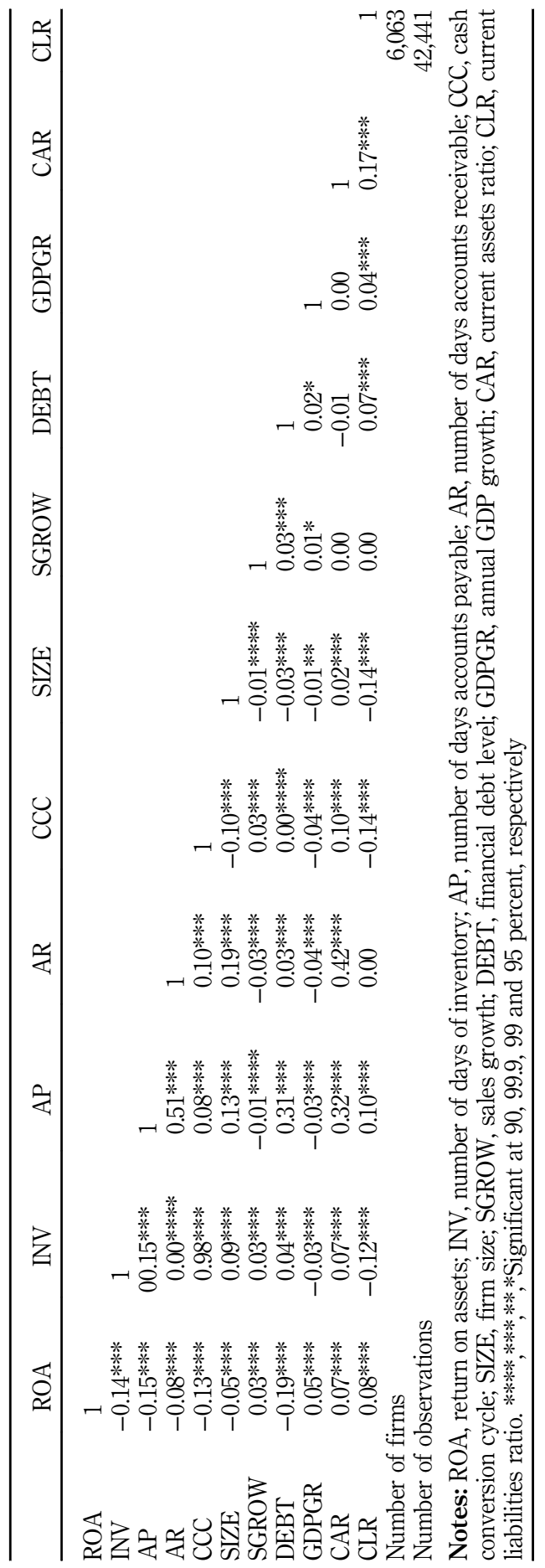




\begin{tabular}{|c|c|c|c|c|c|}
\hline Variable & 1st quartile & 2nd quartile & 3rd quartile & 4th quartile & $t$ \\
\hline Range of ROA & -0.192 to 0.021 & 0.011 to 0.044 & 0.035 to 0.078 & 0.068 to 0.380 & \\
\hline ROA & $\begin{array}{l}-0.010 \\
(0.003)\end{array}$ & $\begin{array}{c}0.028 \\
(0.03)\end{array}$ & $\begin{array}{c}0.053 \\
(0.05)\end{array}$ & $\begin{array}{l}0.119 \\
(0.10)\end{array}$ & $\begin{array}{r}-240.947 \\
(0.000)\end{array}$ \\
\hline INV & $\begin{array}{l}214.17 \\
(114.06)\end{array}$ & $\begin{array}{c}203.71 \\
(109.90)\end{array}$ & $\begin{array}{c}167.73 \\
(89.20)\end{array}$ & $\begin{array}{l}111.18 \\
(58.87)\end{array}$ & $\begin{array}{r}29.301 \\
(0.000)\end{array}$ \\
\hline AP & $\begin{array}{l}72.19 \\
(63.95)\end{array}$ & $\begin{array}{c}76.49 \\
(71.03)\end{array}$ & $\begin{array}{c}70.69 \\
(65.70)\end{array}$ & $\begin{array}{c}56.04 \\
(50.28)\end{array}$ & $\begin{array}{r}25.456 \\
(0.000)\end{array}$ \\
\hline AR & $\begin{array}{c}74.89 \\
(68.88)\end{array}$ & $\begin{array}{c}78.34 \\
(75.49)\end{array}$ & $\begin{array}{c}74.68 \\
(73.07)\end{array}$ & $\begin{array}{c}66.21 \\
(64.41)\end{array}$ & $\begin{array}{r}12.155 \\
(0.000)\end{array}$ \\
\hline $\mathrm{CCC}$ & $\begin{array}{r}216.88 \\
(123.57)\end{array}$ & $\begin{array}{c}205.56 \\
(120.71)\end{array}$ & $\begin{array}{c}171.73 \\
(101.59)\end{array}$ & $\begin{array}{l}121.34 \\
(78.64)\end{array}$ & $\begin{array}{c}27.284 \\
(0.000)\end{array}$ \\
\hline SIZE & $\begin{array}{c}7.67 \\
(7.55)\end{array}$ & $\begin{array}{c}7.72 \\
(7.62)\end{array}$ & $\begin{array}{c}7.64 \\
(7.55)\end{array}$ & $\begin{array}{c}7.51 \\
(7.41)\end{array}$ & $\begin{array}{r}11.640 \\
(0.000)\end{array}$ \\
\hline SGROW & $\begin{array}{r}0.001 \\
(-0.03)\end{array}$ & $\begin{array}{c}0.075 \\
(0.01)\end{array}$ & $\begin{array}{c}0.099 \\
(0.03)\end{array}$ & $\begin{array}{l}0.143 \\
(0.06)\end{array}$ & $\begin{array}{r}-7.208 \\
(0.000)\end{array}$ \\
\hline DEBT & $\begin{array}{c}0.59 \\
(0.62)\end{array}$ & $\begin{array}{c}0.63 \\
(0.66)\end{array}$ & $\begin{array}{c}0.62 \\
(0.66)\end{array}$ & $\begin{array}{c}0.52 \\
(0.55)\end{array}$ & $\begin{array}{c}24.035 \\
(0.000)\end{array}$ \\
\hline CAR & $\begin{array}{c}0.60 \\
(0.66)\end{array}$ & $\begin{array}{c}0.63 \\
(0.69)\end{array}$ & $\begin{array}{c}0.65 \\
(0.71)\end{array}$ & $\begin{array}{c}0.66 \\
(0.73)\end{array}$ & $\begin{array}{r}-15.521 \\
(0.000)\end{array}$ \\
\hline CLR & $\begin{array}{c}0.71 \\
(0.77)\end{array}$ & $\begin{array}{c}0.73 \\
(0.78)\end{array}$ & $\begin{array}{c}0.73 \\
(0.78)\end{array}$ & $\begin{array}{c}0.75 \\
(0.81)\end{array}$ & $\begin{array}{r}-14.593 \\
(0.000)\end{array}$ \\
\hline $\begin{array}{l}\text { Number of firms } \\
\text { Number of obse }\end{array}$ & rvations & & & & $\begin{array}{c}6,063 \\
42,441\end{array}$ \\
\hline
\end{tabular}

Notes: ROA, return on assets; INV, number of days of inventory; AP, number of days accounts payable; AR, number of days accounts receivable; CCC, cash conversion cycle; SIZE, firm size; SGROW, sales growth; DEBT, financial debt level; CAR, current assets ratio; CLR, current liabilities ratio. $t$-statistic tests difference of means between fourth and first quartile, with $p$-value in parentheses. The INV, AP, AR and CCC variables are expressed in number of days; the ROA, SIZE, SGROW, DEBT, CAR and CLR variables are dimensionless. Comparison of mean values of variables in function of ROA quartiles, created annually. Median values in parentheses

Table IV. Mean values by ROA quartiles

However, companies with lower profitability (first quartile) are not the ones with the highest value for the variable SIZE, nor are those more indebted.

In what pertains to the control variables SGROW, CAR and CLR, these results confirm the positive correlation indicated in the correlation matrix, since it is in the higher profitability group that is found the maximum value for this indicator.

The results obtained when carrying out the univariate analysis for two most representative sectors are very similar to those obtained for the whole sample.

The results for the estimation on the equations from Section 2.3 are presented in Table $\mathrm{V}$.

The inverse relationship of the INV, AP, AR and CCC variables with the dependent variable ROA, confirms the results obtained from the correlation matrix. Although providing additional credit to the final consumer and possessing a larger inventory is bound to potentiate an increase in sales, these results seem to imply that the outperformance results are in favor of maintaining both a low number of days of inventory and number of days accounts receivable.

However, this inverse relationship may stem from the influence of the dependent variable over the independent variables and these results be affected by endogeneity problems. In that way, the negative relationship with profitability can be attributed to 


\begin{tabular}{|c|c|c|c|c|c|}
\hline \multirow{3}{*}{$\begin{array}{l}\mathrm{IJM} \\
11,3\end{array}$} & INV & $\begin{array}{l}-2.5 \times 10^{-5} \\
(-1713)^{* * *}\end{array}$ & & & \\
\hline & $\mathrm{AP}$ & & $\begin{array}{l}-1.4 \times 10^{-4} \\
(-17.08)^{* * *}\end{array}$ & & \\
\hline & $\mathrm{AR}$ & & & $\begin{array}{l}-1.4 \times 10^{-4} \\
(-18.47)^{* * * *}\end{array}$ & \\
\hline \multirow[t]{10}{*}{350} & $\mathrm{CCC}$ & & & & $-2.5 \times 10^{-5}$ \\
\hline & SIZE & $\begin{array}{l}3.9 \times 10^{-3} \\
(4.56)^{* * *}\end{array}$ & $\begin{array}{l}5.1 \times 10^{-3} \\
(5.89)^{* * *}\end{array}$ & $\begin{array}{l}5.4 \times 10^{-3} \\
(6.30)^{* * * *}\end{array}$ & $\begin{array}{l}4.0 \times 10^{-3} \\
(4.65) * * *\end{array}$ \\
\hline & SGROW & $\begin{array}{l}5.6 \times 10^{-4} \\
(5.40) * * *\end{array}$ & $\begin{array}{l}5.9 \times 10^{-4} \\
(5.67)^{* * * *}\end{array}$ & $\begin{array}{l}5.7 \times 10^{-4} \\
(5.55)^{* * * *}\end{array}$ & $\begin{array}{l}5.6 \times 10^{-4} \\
(5.37)^{* * * *}\end{array}$ \\
\hline & DEBT & $-1.1 \times 10^{-1}$ & $-1.0 \times 10^{-1}$ & $-1.1 \times 10^{-1}$ & $-1.1 \times 10^{-1}$ \\
\hline & GDPGR & $\begin{array}{l}(-40.56)^{* * *} \\
1.8 \times 10^{-3} \\
(13.43) * * * *\end{array}$ & $\begin{array}{l}(-36.31)^{* * *} \\
1.8 \times 10^{-3} \\
(13.44)^{* * * *}\end{array}$ & $\begin{array}{l}(-40.00)^{* * * *} \\
1.8 \times 10^{-3} \\
(1318) * * *\end{array}$ & $\begin{array}{l}(-41.11)^{* * *} \\
1.8 \times 10^{-3} \\
(13.36) * * * *\end{array}$ \\
\hline & CAR & $\begin{array}{l}1.7 \times 10^{-3} \\
(1.62)\end{array}$ & $\begin{array}{l}1.2 \times 10^{-2} \\
(9.86)^{* * *}\end{array}$ & $\begin{array}{l}1.4 \times 10^{-2} \\
(10.92)^{* * * *}\end{array}$ & $\begin{array}{l}2.0 \times 10^{-3} \\
(1.87)^{*}\end{array}$ \\
\hline & CLR & $\begin{array}{l}1.3 \times 10^{-2} \\
(8.69)^{* * * *}\end{array}$ & $\begin{array}{l}1.8 \times 10^{-2} \\
(12.09)^{* * *}\end{array}$ & $\begin{array}{l}1.4 \times 10^{-2} \\
(9.82)^{* * * *}\end{array}$ & $\begin{array}{l}1.2 \times 10^{-2} \\
(8.21)^{* * * *}\end{array}$ \\
\hline & $F$ & 0.00 & 0.00 & 0.00 & 0.00 \\
\hline & Hausman & 0.00 & 0.00 & 0.00 & 0.00 \\
\hline & No. of obs. & 42,441 & 42,441 & 42,441 & 42,441 \\
\hline
\end{tabular}

Table V.

Effects of working capital on ROA (using fixed-effects)
Notes: INV, number of days of inventory; AP, number of days accounts payable; AR, number of days accounts receivable; CCC, cash conversion cycle; SIZE, firm size; SGROW, sales growth; DEBT, financial debt level; GDPGR, annual GDP growth; CAR, current assets ratio; CLR, current liabilities ratio. Results obtained using fixed-effects estimation. $t$-statistic test in parentheses. $F$ and Hausman are the $p$-value for the testes. $* * * *, * * * * * * *$ Significant at $90,99.9,99$, and 95 percent, respectively

the tendency that companies with lower profitability have to provide their customers with extended terms of payment, have the inventory increased by declining sales and delaying payments to their suppliers (Deloof, 2003; García-Teruel and Martínez-Solano, 2007).

In the integrated analysis of these three variables through the $\mathrm{CCC}$ variable, the results are consistent with the study of García-Teruel and Martínez-Solano (2007), showing that by shortening the cash conversion cycle the firms may improve their profitability. In this case, the results obtained by Karadagli (2012), in which an increase in the cash conversion cycle can help improve the SMEs performance, are not confirmed.

In what concerns the control variables SGROW, GDPGR, CLR and DEBT, the relation with profitability found in the correlation matrix, which is positive for the first three and negative with the last one, is confirmed. It can be concluded that firm profitability decreases with an increase in debt, and increase with a higher percentage of current liabilities in total liabilities, i.e., with aggressive financial politics, and in contexts of economic favorable cycles, probably favoring themselves an increase on sales. These results are consistent with previous studies (see Deloof, 2003; BañosCaballero et al., 2012; García-Teruel and Martínez-Solano, 2007).

With respect to the CAR and SIZE variables, the first one, with a positive relationship in both analyses (correlation and regression), loses its meaning in some regressions, which does not confirm that more conservative investment policies can be 
favoring of profitability, and the second one, although significant in both analyses, shows a negative correlation with profitability while using this regression analysis a positive relationship in the four equations of the study is visible. The reason for this reversal of the relation lies probably on the control of specific unobservable characteristics of firms, as obtained by the method of fixed effects.

\subsection{Robustness and endogeneity}

Aiming at evaluating the robustness of the results, the equations were recalculated using a proxy of the independent variables, defined in a way similar to other studies in international markets (Deloof, 2003; García-Teruel and Martínez-Solano, 2007) and return on invested capital (ROIC), as proxy for profitability. The results are, again, similar to those obtained using the variables determined for the Portuguese situation, making them robust (for concision, these results are not presented, being available upon request).

To control the possible effect of this endogeneity problem, the regression of the equations was made also resorting to instrumental variables. The first lags of the INV, $\mathrm{AP}, \mathrm{AR}$ and $\mathrm{CCC}$ variables were used as an instrument. Table VI presents the results.

The results are similar to those found in Table V, except for the AR variable, which displays a positive relationship. In this sense, this result does not confirm the negative effect that a decision to provide customers with extended terms of payment may have on corporate profitability and can be explained because the costumers require, from firms with declining profitability, more time to assess the quality of products (Deloof, 2003).

\begin{tabular}{lllll}
\hline INV & $-5.2 \times 10^{-5}$ & & & \\
AP & $(-3.76)^{* * * *}$ & & & \\
& & $-4.0 \times 10^{-4}$ & & \\
AR & & $(-4.97)^{* * *}$ & & \\
& & & & \\
CCC & & $\left(4.0 \times 10^{-4}\right.$ & \\
& & & $-7.5 \times 10^{-5}$ \\
SIZE & & & $(-2.62)^{* * * *}$ \\
& $2.8 \times 10^{-2}$ & $-1.1 \times 10^{-2}$ & $5.6 \times 10^{-3}$ & $4.1 \times 10^{-2}$ \\
SGROW & $(2.55)^{* * *}$ & $(-3.42)^{* * *}$ & $(1.01)$ & $(2.01)^{* *}$ \\
& $-1.7 \times 10^{-2}$ & $2.4 \times 10^{-3}$ & $2.3 \times 10^{-2}$ & $-3.1 \times 10^{-2}$ \\
DEBT & $(-0.55)$ & $(0.11)$ & $(1.05)$ & $(-0.64)$ \\
& $9.9 \times 10^{-2}$ & $-1.7 \times 10^{-2}$ & $-4.4 \times 10^{-2}$ & $1.6 \times 10^{-1}$ \\
GDPGR & $(1.18)$ & $(-0.41)$ & $(-0.99)$ & $(1.10)$ \\
& $3.4 \times 10^{-3}$ & $-4.6 \times 10^{-4}$ & $-4.1 \times 10^{-2}$ & $1.5 \times 10^{-2}$ \\
CAR & $(0.05)$ & $(-0.01)$ & $(-0.73)$ & $(0.15)$ \\
& $-2.5 \times 10^{-2}$ & $5.8 \times 10^{-3}$ & $-1.4 \times 10^{-1}$ & $-2.2 \times 10^{-3}$ \\
CLR & $(-2.22)^{* *}$ & $(0.47)$ & $(-5.60)^{* * *}$ & $(-0.09)$ \\
& $-2.8 \times 10^{-1}$ & $2.4 \times 10^{-1}$ & $1.4 \times 10^{-1}$ & $-4.9 \times 10^{-1}$ \\
No. of obs. & $(-1.34)$ & $(3.41)^{* * *}$ & $(1.39)$ & $(-1.30)$ \\
Notes: & 36,378 & 36,378 & 36,378 & 36,378
\end{tabular}

Notes: INV, number of days of inventory; AP, number of days accounts payable; AR, number of days accounts receivable; CCC, cash conversion cycle; SIZE, firm size; SGROW, sales growth; DEBT, financial debt level; GDPGR, annual GDP growth; CAR, current assets ratio; CLR, current liabilities ratio. Results obtained from estimation using instrumental variables. The first lag of $\mathrm{INV}, \mathrm{AP}, \mathrm{AR}$, and CCC variables were the instruments used. $z$-statistic test in parentheses. $* * * * * * * * * * * *$ Significant at 90 , 99.9, 99, and 95 percent, respectively

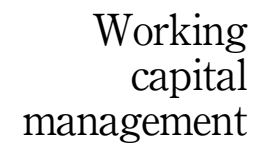

351
Table VI.

Effects of working capital on ROA (using instrumental variables) 


\section{IJMF \\ 11,3}

352

\subsection{Industry effects}

With the purpose of controlling the industry effect, since firms have diverse and unique characteristics for each sector (Hawawini et al., 1986; Weinraub and Visscher, 1998; Filbeck and Krueger, 2005), the ROA, ROIC and cash conversion cycle were considered to be sectorial characteristics and so, their respective means were subtracted from the variables ROA, ROIC and CCC.

The results using centered CCC (selected as representative) are presented in Table VII, and are similar to those obtained previously with the fixed effects approach, which reinforces the robustness of our results (the other centered combinations yield similar results and are also omitted, to conserve space).

To explicitly control for industry effects, and because of the time invariant nature of the industry classification, we also run an alternative empirical strategy. Specifically, we pool the data on each firm in each year and estimate (by OLS) the following regression:

$$
\begin{aligned}
D E P_{i t}= & \beta_{0}+\beta_{1} E X P_{i t}+\beta_{2} S I Z E_{i t}+\beta_{3} S G R O W_{i t}+\beta_{4} D E B T_{i t} \\
& +\beta_{5} G D P G R_{i t}+\beta_{6} C A R_{i t}+\beta_{7} C L R_{i t}+\sum_{j=B}^{S} \beta_{j} I D_{i j}+\varepsilon_{i t}
\end{aligned}
$$

where DEP stands for ROA or ROIC, and EXP are the explanatory variables of interest, that is INV, AP, AR and CCC. The control variables, SIZE, SGROW, DEBT, GDPGR, CAR and CLR, retain their usual meaning and the ID variables are industry-specific dummy variables that equal 1 if a specific industry includes a given firm and 0 otherwise. To avoid the dummy variable trap we omit sector A (agriculture, forestry

\begin{tabular}{lcc}
\hline & ROA & ROIC \\
\hline Centered CCC & $-2.5 \times 10^{-5}$ & $-3.9 \times 10^{-5}$ \\
& $(-17.50)^{* * *}$ & $(-20.24)^{* * *}$ \\
SIZE & $4.0 \times 10^{-3}$ & $4.1 \times 10^{-3}$ \\
& $(4.64)^{* * *}$ & $(3.68)^{* * *}$ \\
SGROW & $5.6 \times 10^{-4}$ & $7.1 \times 10^{-4}$ \\
& $(5.37)^{* * *}$ & $(5.20)^{* * *}$ \\
DEBT & $-1.1 \times 10^{-1}$ & $-1.1 \times 10^{-2}$ \\
& $(-41.11)^{* * *}$ & $(-31.26)^{* * *}$ \\
GDPGR & $1.8 \times 10^{-3}$ & $2.6 \times 10^{-3}$ \\
& $(13.36)^{* * *}$ & $(14.40)^{* * *}$ \\
CAR & $2.0 \times 10^{-3}$ & $3.0 \times 10^{-2}$ \\
& $(1.87)^{* * * *}$ & $(21.23)^{* * *}$ \\
CLR & $1.2 \times 10^{-2}$ & $2.6 \times 10^{-2}$ \\
& $(8.20)^{* * *}$ & $(13.62)^{* * *}$ \\
$F$ & 0.00 & 0.00 \\
Hausman & 0.00 & 0.00 \\
No. of obs. & 42,441 & 42,441
\end{tabular}

Table VII.

Effects of working capital on ROA and ROIC (using centered CCC)
Notes: Centered CCC, sector-demeaned cash conversion cycle; SIZE, firm size; SGROW, sales growth; DEBT, financial debt level; GDPGR, annual GDP growth; CAR, current assets ratio; CLR, current liabilities ratio. The second and third columns refer to the regression with ROA as dependent variable. The fourth and fifth columns to the regression with ROIC as dependent variable. $t$-statistic test in parentheses. $* * * * * * * * * * * *$ Significant at $90,99.9,99$, and 95 percent, respectively 
and fishing). Also we present heteroskedasticity and autocorrelation (HAC) robust standard errors.

Table VIII presents these results. Each line refers to the test of a specific relevant explanatory variable, either INV, AP, AR or CCC. The two columns refer to each dependent variable, ROA or ROIC. Thus, Table VII summarizes eight different models.

To be concise and facilitate the presentation of the main results, we do not present the estimated coefficients of the control variables nor those of the individual industry effect. Globally, the control variables coefficients allow for the same conclusions as before. Concerning the industry-specific coefficients, we note that, in the eight models estimated, they retain statistical significance for all the industries with the exception of industry B (mining and quarrying and industry), R (arts, entertainment and recreation), both in the ROA and in the ROIC regression. In other words, the present study shows that for those two industries, the specific industries effects are not statistically different from the base industry we define (A - agriculture, forestry and fishing).

Most relevant, the basic result remains: there is a highly significant negative relation between all the parameters that describe the financial management of operations, either $\mathrm{INV}, \mathrm{AP}, \mathrm{AR}$ and $\mathrm{CCC}$ and profitability, favoring the more aggressive short-term financial management policies.

Finally, all regressions for the two most representative sectors of the sample under analysis were conducted separately. The results obtained are aligned with those obtained for the overall sample, except for SIZE variable of the sector G (wholesale and retail trade, repair of motor vehicles and motorcycles), which shows a negative relationship with profitability, but with low statistical significance (to conserve space these results are not presents but are available upon request).

\begin{tabular}{|c|c|c|}
\hline & $\mathrm{ROA}$ & ROIC \\
\hline INV & $\begin{array}{l}-2.8 \times 10^{-5} \\
(-23.49)^{* * *}\end{array}$ & $\begin{array}{l}-4.2 \times 10^{-5} \\
(-26.87) * * *\end{array}$ \\
\hline $\mathrm{AP}$ & $\begin{array}{l}-1.7 \times 10^{-4} \\
(-30.32)^{* * *}\end{array}$ & $\begin{array}{l}-1.1 \times 10^{-4} \\
(-14.47)^{* * * *}\end{array}$ \\
\hline $\mathrm{AR}$ & $\begin{array}{l}-1.2 \times 10^{-4} \\
(-21.51)^{* * * *}\end{array}$ & $\begin{array}{l}-1.5 \times 10^{-4} \\
(-21.52)^{* * * *}\end{array}$ \\
\hline $\mathrm{CCC}$ & $\begin{array}{l}-2.8 \times 10^{-5} \\
(-23.33)^{* * *}\end{array}$ & $\begin{array}{l}-4.6 \times 10^{-5} \\
(-27.28) * * *\end{array}$ \\
\hline Constant & Yes & Yes \\
\hline Control variables & Yes & Yes \\
\hline Industry dummies & Yes & Yes \\
\hline No. of obs. & 42,441 & 42,441 \\
\hline
\end{tabular}

Notes: This table summarizes eight different models estimated separately using pooled data. Each line refers to a different explanatory variable. INV, number of days of inventory; AP, number of days accounts payable; AR, number of days accounts receivable or CCC-cash conversion cycle. Constant is the constant term, Control variables refer to the set of control variables, SIZE, firm size; SGROW, sales growth; DEBT, financial debt level; GDPGR, annual GDP growth; CAR, current assets ratio; CLR, current liabilities ratio. Industry dummies refer to the set of industry specific classification dummy variables. The second and third columns refer to the regression with ROA as dependent variable. The fourth and fifth columns to the regression with ROIC as dependent variable. $t$-statistic test in parentheses. *************Significant at $90,99.9,99$, and 95 percent, respectively

Table VIII.

Effects of working capital on ROA and ROIC (using pooled regressions) 
IJMF

11,3

354

\subsection{Non-linear effects}

Most recent studies (Silva, 2011; Baños-Caballero et al., 2012; Gomes, 2013) found the existence of a non-monotonic relationship between working capital level and firm profitability, which indicates that firms have an optimal working capital level that maximizes their profitability. In order to find a non-linear relationship between working capital level and firm profitability the following additional regressions were made:

$$
\begin{aligned}
R O A_{i t}= & \beta_{0}+\beta_{1} I N V_{i t}+\beta_{2} I N V_{i t}^{2}+\beta_{3} S I Z E_{i t}+\beta_{4} S G R O W_{i t}+\beta_{5} D E B T_{i t} \\
& +\beta_{6} G D P G R_{i t}+\beta_{7} C A R_{i t}+\beta_{8} C L R_{i t}+v_{i}+\varepsilon_{i t} \\
R O A_{i t}= & \beta_{0}+\beta_{1} A P_{i t}+\beta_{2} A P_{i t}^{2}+\beta_{3} S I Z E_{i t}+\beta_{4} S G R O W_{i t}+\beta_{5} D E B T_{i t} \\
& +\beta_{6} G D P G R_{i t}+\beta_{7} C A R_{i t}+\beta_{8} C L R_{i t}+v_{i}+\varepsilon_{i t} \\
R O A_{i t}= & \beta_{0}+\beta_{1} A R_{i t}+\beta_{2} A R_{i t}^{2}+\beta_{3} S I Z E_{i t}+\beta_{4} S G R O W_{i t}+\beta_{5} D E B T_{i t} \\
& +\beta_{6} G D P G R_{i t}+\beta_{7} C A R_{i t}+\beta_{8} C L R_{i t}+v_{i}+\varepsilon_{i t} \\
R O A_{i t}= & \beta_{0}+\beta_{1} C C C_{i t}+\beta_{2} C C C_{i t}^{2}+\beta_{3} S_{Z I E_{i t}}+\beta_{4} S G R O W_{i t}+\beta_{5} D E B T_{i t} \\
& +\beta_{6} G D P G R_{i t}+\beta_{7} C A R_{i t}+\beta_{8} C L R_{i t}+v_{i}+\varepsilon_{i t}
\end{aligned}
$$

Dependent, independent and control variables are specified as before. The difference in these regressions consists on the addition of a square value on INV, AP, AR and CCC.

It is seen in Table IX that the coefficients for the squared terms of the variables INV, $\mathrm{AP}, \mathrm{AR}$ and CCC are significant, and positive, which indicates a relevant quadratic dependence and the presence of a minimum, respectively. This minimum is found for large values of those variables, thus suggesting an overall decreasing trend of ROA as these variables increase. Previous works (Silva, 2011; Baños-Caballero et al., 2012; Gomes, 2013) have suggested a negative value for the same coefficients, with a maximum located for low values of the independent variables. Again, this suggests a decreasing trend of ROA with increasing values of the latter variables.

\section{Conclusions}

Given the crisis that has been felt since 2008, an efficient working capital management has become vital for the small and medium-sized group of Portuguese firms. In this context, this work intends to obtain empirical evidence on the effects of working capital management on the profitability of SMEs. For this purpose, a sample of 6,063 Portuguese SMEs was used, covering the time period 2002-2009, resulting from extensive preliminary filters, after which several techniques from statistics and econometrics were applied. Among them, stands out the panel data treatment, with the fixed-effects regression, considered the most suitable after tests performed for the analyses that were conducted.

In this study, a negative relationship with profitability was found for INV, AP, AR and CCC variables, results that are aligned with other analyses performed in different business contexts (Deloof, 2003; García-Teruel and Martínez-Solano, 2007; Falope and Ajilore, 2009). 


\begin{tabular}{|c|c|c|c|c|c|}
\hline INV & $\begin{array}{l}-6.7 \times 10^{-5} \\
(-23.85)^{* * *}\end{array}$ & & & & $\begin{array}{r}\text { Working } \\
\text { capital }\end{array}$ \\
\hline $\mathrm{INV}^{2}$ & $\begin{array}{l}1.4 \times 10^{-8} \\
(17.44)^{* * * *}\end{array}$ & & & & management \\
\hline $\mathrm{AP}$ & & $\begin{array}{l}-2.4 \times 10^{-4} \\
(-12.85)^{* * *}\end{array}$ & & & \\
\hline $\mathrm{AP}^{2}$ & & $\begin{array}{l}4.7 \times 10^{-7} \\
(6.13)^{* * * *}\end{array}$ & & & 355 \\
\hline $\mathrm{AR}$ & & & $\begin{array}{l}-1.5 \times 10^{-4} \\
(-8.93)^{* * * *}\end{array}$ & & \\
\hline $\mathrm{AR}^{2}$ & & & $\begin{array}{l}6.3 \times 10^{-8} \\
(0.90)\end{array}$ & & \\
\hline $\mathrm{CCC}$ & & & & $\begin{array}{l}-6.3 \times 10^{-5} \\
(-23.45)^{* * * *}\end{array}$ & \\
\hline $\mathrm{CCC}^{2}$ & & & & $\begin{array}{l}1.4 \times 10^{-8} \\
(16.60)^{* * * *}\end{array}$ & \\
\hline SIZE & $\begin{array}{l}4.7 \times 10^{-3} \\
(5.45)^{* * * *}\end{array}$ & $\begin{array}{l}5.5 \times 10^{-3} \\
(6.32)^{* * * *}\end{array}$ & $\begin{array}{l}5.5 \times 10^{-3} \\
(6.33)^{* * * *}\end{array}$ & $\begin{array}{l}4.7 \times 10^{-3} \\
(5.55)^{* * * *}\end{array}$ & \\
\hline SGROW & $\begin{array}{l}5.2 \times 10^{-4} \\
(5.09)^{* * * *}\end{array}$ & $\begin{array}{l}5.9 \times 10^{-4} \\
(5.67)^{* * * *}\end{array}$ & $\begin{array}{l}5.7 \times 10^{-4} \\
(5.54)^{* * * *}\end{array}$ & $\begin{array}{l}5.3 \times 10^{-4} \\
(5.09)^{* * * *}\end{array}$ & \\
\hline DEBT & $\begin{array}{l}-1.1 \times 10^{-1} \\
(-40.05)^{* * *}\end{array}$ & $\begin{array}{l}-1.0 \times 10^{-1} \\
(-35.77)^{* * * *}\end{array}$ & $\begin{array}{l}-1.1 \times 10^{-1} \\
(-40.00)^{* * *}\end{array}$ & $\begin{array}{l}-1.1 \times 10^{-1} \\
(-41.36)^{* * *}\end{array}$ & \\
\hline GDPGR & $\begin{array}{l}1.8 \times 10^{-3} \\
(13.03)^{* * * *}\end{array}$ & $\begin{array}{l}1.8 \times 10^{-3} \\
(13.56)^{* * * *}\end{array}$ & $\begin{array}{l}1.8 \times 10^{-3} \\
(13.19)^{* * * *}\end{array}$ & $\begin{array}{l}1.8 \times 10^{-3} \\
(12.96)^{* * * *}\end{array}$ & \\
\hline CAR & $\begin{array}{l}2.5 \times 10^{-3} \\
(2.35)^{*}\end{array}$ & $\begin{array}{l}1.7 \times 10^{-2} \\
(11.60)^{* * * *}\end{array}$ & $\begin{array}{l}1.4 \times 10^{-2} \\
(10.22)^{* * *}\end{array}$ & $\begin{array}{l}3.0 \times 10^{-3} \\
(2.88)^{* *}\end{array}$ & \\
\hline CLR & $\begin{array}{l}1.2 \times 10^{-2} \\
(8.33)^{* * * *}\end{array}$ & $\begin{array}{l}1.8 \times 10^{-2} \\
(12.45)^{* * * *}\end{array}$ & $\begin{array}{l}1.4 \times 10^{-2} \\
(9.81)^{* * * *}\end{array}$ & $\begin{array}{l}1.1 \times 10^{-2} \\
(7.30)^{* * * *}\end{array}$ & \\
\hline$F$ & 0.00 & 0.00 & 0.00 & 0.00 & \\
\hline Hausman & 0.00 & 0.00 & 0.00 & 0.00 & \\
\hline No. of obs. & 42,441 & 42,441 & 42,441 & 42,441 & Effects of working \\
\hline \multicolumn{5}{|c|}{$\begin{array}{l}\text { Notes: INV, number of days of inventory; AP, number of days accounts payable; AR, number of days } \\
\text { accounts receivable; CCC, cash conversion cycle; SIZE, firm size; SGROW, sales growth; DEBT, } \\
\text { financial debt level; GDPGR, annual GDP growth; CAR, current assets ratio; CLR, current liabilities } \\
\text { ratio. Results obtained using fixed-effects estimation. } t \text {-statistic test in parentheses. F and Hausman are } \\
\text { the } p \text {-value for the testes. } * * * * * * * * * * \text {, Significant at } 90,99.9,99 \text {, and } 95 \text { percent, respectively }\end{array}$} & $\begin{array}{r}\text { capital on ROA } \\
\text { testing for a } \\
\text { non-linear } \\
\text { relationship (using } \\
\text { fixed-effects) }\end{array}$ \\
\hline
\end{tabular}

In order to control also for possible endogeneity problems, an alternative, consisting on the regression with instrumental variables, using the first lag of the INV, AP, AR and CCC variables as an instrument was employed. The results are similar to those obtained with the fixed effects regression except for the AR variable, which displays a positive relationship. In this sense, this result does not confirm the negative effect that a decision to provide customers with extended terms of payment may have on corporate profitability and could be explained because the costumers require, from firms with declining profitability, more time to assess the quality of products (Deloof, 2003).

Regarding the control variables SIZE, SGROW, GDPGR, CLR and DEBT, all of them statistically significant, the relation with profitability is positive for the first four, and negative for the last one. It can be assumed that firm profitability decreases with the increase in debt and increases in contexts of economic favorable cycles, probably favoring themselves an increase in sales and with an aggressive financial politics. These results are consistent with previous studies (e.g. Deloof, 2003; Baños-Caballero et al., 2012; García-Teruel and Martínez-Solano, 2007). 
IJMF 11,3

In order to draw comparisons between the results obtained for the Portuguese market, and those previously obtained in other international markets, regressions were carried out using alternative definitions of the independent variables. The results now obtained are similar to those of previous studies. Regressions were also performed for the cash conversion cycle, using an alternative variable for profitability, measured by ROIC. This analysis confirmed the robustness of the results of the present work.

Once the sample under study consists of companies of various types, it was deemed necessary to take the specific characteristics of each sector into account. The trends obtained are again similar, thus confirming the robustness of the results. Also, all regressions were performed for the two most representative sectors of the sample under analysis. The results obtained are aligned with those obtained for the overall sample.

Finally, it was also found a significant quadratic dependence on the variables INV, $\mathrm{AP}, \mathrm{AR}$ and $\mathrm{CCC}$, and a decreasing trend of $\mathrm{ROA}$ with increasing values of these variables.

In general, those results indicate that a practice of more aggressive working capital management policies increase firms profitability. In particular, evidence was found for the existence of an optimal level for the working capital components, clues that may be important to managers of Portuguese SMEs be aware of the importance of a good practice in working capital management, since the costs associated with a distancing (by excess or defect) of its optimal value are quite high and therefore with implications for profitability.

An issue for further research is to study the relevance of firm managers' sentiment for the relation between the efficiency of working capital management and corporate profitability. Indeed, more optimistic managers, because they tend to misestimate the risks involved, may favor more aggressive short-term financial management policies.

\section{References}

Appuhami, B.A.R. (2008), “The impact of firms' capital expenditure on working capital management: an empirical study across industries in Thailand", International Management Review, Vol. 4 No. 1, pp. 11-24.

Atrill, P. (2009), Financial Management for Decision Makers, Pearson Education, Harlow, Essex.

Audretsch, B.D. (2002), “The dynamic role of small firms: evidence from the US", Small Business Economics, Vol. 18 Nos 1-3, pp. 13-49.

Baños-Caballero, S., García-Teruel, P.J. and Martínez-Solano, P. (2012), "How does working capital management affect the profitability of Spanish SMEs?", Small Business Economics, Vol. 39 No. 2, pp. 517-529.

Deloof, M. (2003), "Does working capital management affect profitability of Belgian firms?", Journal of Business Finance \& Accounting, Vol. 30 Nos 3-4, pp. 573-87.

Ellis, C. and Tailor, D. (2011), "The role of entrepreneurs and SMEs in driving the recovery", Research Article, The British Private Equity \& Venture Capital Association, London, June.

Falope, O.I. and Ajilore, O.T. (2009), "Working capital management and corporate profitability: evidence from panel data analysis of selected quoted companies in Nigeria", Research Journal of Business Management, Vol. 3 No. 3, pp. 73-84.

Filbeck, G. and Krueger, T.M. (2005), "An analysis of working capital management results across industries", American Journal of Business, Vol. 20 No. 2, pp. 11-20. 
García-Teruel, P. and Martínez-Solano, P. (2007), "Effects of working capital management on SME profitability", International Journal of Managerial Finance, Vol. 3 No. 2, pp. 164-177.

Gomes, D.F.N. (2013), "How does working capital management affect firms' profitability? Evidence from Portugal”, Master's thesis, Lisboa School of Economics \& Management, Lisbon.

Hawawini, G., Viallet, C. and Vora, A. (1986), "Industry influence on corporate working capital decisions", Sloan Management Review, Vol. 27 No. 4, pp. 15-24.

Jose, M.L., Lancaster, C. and Stevens, J.L. (1996), "Corporate return and cash conversion cycle", Journal of Economics and Finance, Vol. 20 No. 1, pp. 33-46.

Karadagli, E.C. (2012), "The effect of working capital management on the profitability of Turkish SMEs", British Journal of Economics, Finance and Management Sciences, Vol. 5 No. 2, pp. 36-44.

Lazaridis, I. and Tryfonidis, D. (2006), "Relationship between working capital management and profitability of listed companies in the Athens Stock Exchange", Journal of Financial Management and Analysis, Vol. 19 No. 1, pp. 26-38.

Nazir, M.S. and Afza, T. (2009), "Impact of aggressive working capital management policy on firms' profitability”, The IUP Journal of Applied Finance, Vol. 15 No. 8, pp. 19-30.

Raheman, A. and Nasr, M. (2007), "Working capital management and profitability - case of Pakistani firms", International Review of Business Research Papers, Vol. 3 No. 1, pp. 279-300.

Richards, V. and Laughlin, E. (1980), "A cash conversion cycle approach to liquidity analysis", Financial Management, Vol. 9 No. 1, pp. 32-38.

Shah, S.M.A. and Sana, A. (2006), "Impact of working capital management on the profitability of oil and gas sector of Pakistan”, European Journal of Scientific Research, Vol. 15 No. 3, pp. 301-307.

Silva, S.M.S.F.N. (2011), "Effects of working capital management on the profitability of Portuguese manufacturing firms", Master's thesis, Universidade do Minho, Braga.

Van-Horne, J.C. and Wachowicz, J.M. (2008), Fundamentals of Financial Management, Pearson Education, Harlow, Essex.

Weinraub, H.J. and Visscher, S. (1998), "Industry practice relating to aggressive conservative working capital policies", Journal of Financial and Strategic Decision, Vol. 11 No. 2, pp. 11-18.

\section{Further reading}

Petersen, M.A. and Rajan, R.G. (1997), "Trade credit: theories and evidence”, Review of Financial Studies, Vol. 10 No. 3, pp. 661-691.

Shin, H.H. and Soenen, L. (1998), "Efficiency of working capital management and corporate profitability", Financial Practice and Education, Vol. 8 No. 2, pp. 37-45.

Wang, Y.J. (2002), "Liquidity management, operating performance, and corporate value: evidence from Japan and Taiwan”, Journal of Multinational Financial Management, Vol. 12 No. 2, pp. 159-169.

\section{About the authors}

Professor Maria Amélia Pais, graduated in Chemistry from the University of Coimbra and possesses a Master's Degree in Management, from the same university. Presently, she belongs to the board of directors of the Coimbra Sul Group of Schools. 
IJMF

11,3

Paulo Miguel Gama is an Assistant Professor of Finance at the University of Coimbra. He has a $\mathrm{PhD}$ in Management (Finance) and a Master in Management Science from the ISCTE-IUL School of Business, and a BA in Economics from the Faculty of Economics of the University of Coimbra (FEUC). He teaches investments, financial statement analysis and entrepreneurial finance in the undergraduate, graduate and executive programs at the FEUC. He is currently the Sub-Director of the FEUC and Co-Chair of the Executive MBA program and of the Master in Accounting and Finance. His research interests include international investments, corporate finance and behavioral finance. His research has been published in academic journals such as the Journal of Financial and Quantitative Analysis, The Journal of Banking and Finance, and The Journal of Behavioral Finance. He has been a recipient of research grants from the Portuguese Science Foundation. Paulo Miguel Gama is the corresponding author and can be contacted at: pmgama@fe.uc.pt

For instructions on how to order reprints of this article, please visit our website: www.emeraldgrouppublishing.com/licensing/reprints.htm Or contact us for further details: permissions@emeraldinsight.com 
Reproduced with permission of copyright owner. Further reproduction prohibited without permission. 